\title{
¿Puede el cine darnos Qué Pensar? Wong Kar-Wai Y LA POÉTICA DEL DES-ENCUENTRO
}

\author{
Carlos Fernando Alvarado Duque
}

\begin{abstract}
RESUMEN: ¿Puede el cine filosofar? ¿Puede la imagen en movimiento ser medio para que la filosofía opere en otra materia expresiva? Este artículo (derivado de la tesis doctoral en filosofía: Poéticas del cine: marcas de una filosofía en imágenes) tiene como interés auscultar la capacidad de ciertos cines (que tiene origen en el marco del cine moderno) de hacer filosofía al interior de la gran pantalla. Por eso, se exponen las líneas teóricas que permiten la defensa de un cine filosófico capaz de ofrecer conceptos a través de la dimensión expresiva propia de las imágenes en movimiento. Dicho proceso tiene lugar al interior del trabajo poético que el cine de autor ofrece y que, a razón de su distancia del tono general del cine clásico, supone una crítica a la metafísica en el territorio del séptimo arte. Se realiza el análisis de parte de la obra iniciática del director Wong Kar-Wai y su singular poética del des-encuentro (nominación que introducimos para caracterizar las marcas de autor del cineasta hongkonés). A razón de su trabajo al filo del cine moderno es posible evidenciar cómo el cine puede darnos qué pensar.
\end{abstract}

Palabras Clave: Cine. Filosofía. Poética. Metafísica. Wong Kar-Wai.

El cine transforma la filosofia, es decir, que el cine transforma la noción misma de idea. En el fondo,

el cine es la creación de nuevas ideas sobre lo que es una idea.

Alain Badiou

\footnotetext{
${ }_{1}$ Profesor Titular de la Escuela de Comunicación Social y Periodismo de la Universidad de Manizales, Caldas-Colombia. (D) https://orcid.org/0000-0003-4126-3133 E-mail: cfalvarado@umanizales.edu.co Doctor en Filosofía de la Universidad de Antioquia, Magister en Filosofía de la Universidad de Caldas, Filósofo de la Universidad de Caldas, Especialista en Estética de la Universidad Nacional de Colombia, Comunicador Social y Periodista y miembro del Grupo de Investigaciones de la Comunicación de la Universidad de Manizales.
}

http://dx.doi.org/10.1590/0101-3173.2019.v42n3.10.p171 


\section{INTRODUCCIÓN}

Pensar las relaciones entre la filosofía y el cine condujo a que el esfuerzo investigativo, base de este trabajo, indagará por el modo en que el séptimo arte puede dar cuerpo a la filosofía. La tesis, tras esta pesquisa, sostiene que la capacidad de renovación poética propia del cine de autor ofrece una maleabilidad de la dimensión expresiva del séptimo arte que da pie a otros modos de enunciación. $Y$ en esas variaciones discursivas es posible que el cine filosofe, dé cuerpo a ideas reformulando la aparente vocación representativa de las imágenes en movimiento. Si bien nuestro interés ha sido sugerir que en el cine de autor puede hallarse un terreno fértil para un cine capaz de darnos que pensar, para que los conceptos puedan ser materializados en un nueva materia, no excluimos que dicha cualidad o virtud pueda hallarse en otros cines. En otras palabras, es posible, no cabe duda, que obras pertenecientes a la gran industria ofrezcan esta misma dinámica. Varios trabajos, como el de Stanely Cavell, La búsqueda de la felicidad: la comedia de enredo matrimonial de Hollywood (1999), son un claro ejemplo de ello. Sumado a esto, vale la pena aclarar que no asumimos la figura del autor en una clave romántica como quizá pueda pensarse en algunas posturas de la política de autor de los años sesentas del siglo pasado. La figura del autor tiene tanto de las refracciones biográficas de un cineasta, como del hecho de que opera en un sistema textual que no se desconecta de un gran ramaje de referencias e interconexiones con un sistema representativo.

Desplegamos un análisis de la obra iniciática ${ }^{2}$ del director hongkonés Wong Kar-Wai para sostener que su poética tiene la virtud de crear conceptosimágenes a través de imágenes en movimiento (lo cual fortalece la tentación de un cine filosófico). En tal dinámica se revela cómo la impronta moderna de la filmografía de este cineasta evita todo antojo metafísico a través de su inclinación por, la que podemos definir como una poética del des-encuentro. Presentaremos en la primera parte del texto una caracterización de las relaciones entre cine y filosofía que recogen varios trabajos que horadan el terreno de estudio. Luego de ello, de la mano de Deleuze y Badiou, una definición concreta de la filosofía que permita pensar su expansión al territorio de las imágenes en movimiento. Por último una defensa del cine de autor como mecanismo poético que permite el tránsito de la filosofía el cine. Ello sumado al análisis de la obra de Wong Kar-Wai que oficia de ejemplificación.

\footnotetext{
2 Por imposibilidad de acceso al material de análisis, se excluyen dos filmes de la obra iniciática del director: As tears go by (1988) y Ashes of time (1994).
} 
Iniciamos por señalar que las relaciones entre filosofía y cine se han engrosado de una manera significativa en los últimos treinta años. Destacados filósofos del siglo XX y XXI (de muy diferentes escuelas y con intereses filosóficos dispares) han hecho del séptimo arte un objeto de estudio ${ }^{3}$, un motivo para ilustrar, en clave didáctica, ideas o posturas ${ }^{4}$ y han encontrado, a su interior, otro modo de filosofar ${ }^{5}$. En ese marco nos convoca, más que hacer una cartografía de los encuentros y desencuentros entre ambos territorios, seguir una ruta que legitime la potencia de ciertos cines para materializar "situaciones filosóficas" como bien sugiere Badiou (2004). Nuestra hipótesis corre por la que es, tal vez, la menos explorada y más arriesgada de las rutas de encuentro. Creemos que ciertos cines, producto de la modernidad del séptimo arte, tienen la capacidad

${ }^{3}$ Es quizás Noël Carroll (en asocio con Jinhee Choi) quien ha caracterizado un programa de investigación en términos de filosofía del cine. Si el séptimo arte se convierte en objeto de estudio es necesario tematizarlo a través de intereses categoriales: "Una perspectiva filosófica sobre las imágenes en movimiento implica construir marcos conceptuales sobre nuestras prácticas cinematográficas." (CARROL, 2006, p. 1). Por ello propone ocho grandes campos de trabajo orientados por diversos intereses: 1. ¿Qué es una filosofía del cine? 2. Estudios sobre la naturaleza del cine. 3. Análisis de la relación entre filmes y autores. 4. ¿De qué modo el cine produce emociones? 5. Estudio de la dimensión narrativa del séptimo arte. 6. Vínculos entre el cine y la sociedad (dimensión ética). 7. Capacidades filosóficas del cine. 8. Crítica cinematográfica.

4 Wartenberg señala que el cine puede proveer discusiones filosóficas y sus imágenes recurren a mecanismos propios de la filosofía para hacer dichas exposiciones. Entre ellas destaca experimentos, contraejemplos y argumentos presentes en la mayoría del cine de ficción, capaces de dar forma a problemas filosóficos en pantalla. Si bien reconoce que existen limitaciones que no permiten que el séptimo arte suplante el trabajo de la filosofía, como por ejemplo el hecho de que ésta no se inscribe en el género narrativo, considera una ganancia la imbricación de los dos medios. Al respecto señala: "Así, ambos, cine y filosofía, se benefician al yuxtaponerse. Si el cine logra ganar peso cultural gracias a su asocio con la filosofía, la filosofía puede ganar mayores públicos y mayor impacto social al estar en contacto con el cine." (WARTENBERG, 2007, p. 141).

${ }^{5}$ La tarea de un cine filosófico es más arriesgada. Y aunque no se trata de que el cine plantee problemas hasta ahora desconocidos por la filosofía, sí se pretende mostrar otros modos de pensar acontecimientos, relaciones heterogéneas, reconfiguraciones de ideas a partir de las derivas de la imagen-movimiento. Frampton (2006) se aventura a sugerir nuevos conceptos para pensar la relación entre cine y filosofía. De hecho su trabajo titulado Filmosofía plantea que dicho título remite al trabajo filosófico operado en el séptimo arte. De su obra deseamos resaltar un concepto en particular: cine-pensamiento. Dicha figura, dice, no hace referencia al acto externo de pensar el cine, el trabajo del espectador que medita la imagen, sino a la posibilidad de asumir que ciertas imágenes son pensamiento puro. Esa figura supone una conexión entre idea, sentimiento y emoción. Extensión propia de la imagen que despliega un pensamiento por su condición singular, apelando a una afectación emocional del público y poniendo en evidencia una figura inteligible. "El cine, como su propio pensamiento, su propia energía, crea intuitivamente imágenes-conceptos, afectos, perspectivas fracturadas, que se conectan directamente con nuestras mentes." (FRAMPTON, 2006, p. 200). Su idea de una filmosofía no rivaliza con la filosofía tradicional, simplemente ofrece una ruta intuitiva, afectiva para mediar eventos filosóficos. En sus palabras: "[...] al final, más allá de las capacidades filosóficas, la filmosofía es simplemente una ruta alternativa para la filosofía." (FRAMPTON, 2006, p. 185). 
de crear imágenes-pensamiento. Y que, mediante sus propias condiciones enunciativas, dichas imágenes ensanchan el trabajo filosófico.

De entrada este presupuesto es problemático porque supone un cambio en el soporte expresivo de la filosofía. Diríamos que debe hacerse un ejercicio traslaticio de la palabra a la imagen en movimiento. Y si bien no nos interesa alimentar una relación de oposición entre ambas, no puede desconocerse que la distancia entre una filosofía hecha mediante una lengua de base y un sistema expresivo hipocodificado, como el cine, supone una tensión. ¿Es posible filosofar en imágenes? Y, de serlo, ¿la imagen es capaz de dar cuerpo a conceptos? Es importante destacar que la palabra ha sido, históricamente, el vehículo privilegiado de la filosofía; parte de este privilegio se debe a la cercana relación entre el trabajo conceptual y la naturaleza digital de las lenguas. En la medida en que la palabra es un objeto diferencial, es decir, que no guarda semejanza (icónica o perceptiva) con lo que representa, tiene la capacidad de materializar conceptos. La imagen, que en términos semióticos opera en clave analógica, funciona como extensión (diríamos de tipo indicial) de lo que evoca. Ello le depara una cercanía sensible con cualquier objeto, lo cual hace que los conceptos parezcan fuera de su alcance al poseer una naturaleza inmaterial.

Un segundo problema, si bien puede parecer menor, emerge cuando reconocemos que la filosofía, en términos prácticos, necesita de oficiantes. En efecto, la riqueza del filosofar, podríamos decir, radica en el hecho de que tras cierta perspectiva, incluso todo un sistema, se identifica un autor (o, en algunos casos, una voz colectiva, un coro). Lo importante es que en toda filosofía puede encontrarse, con facilidad, un rostro. Y, si se puede creer que exista una noción universal sobre qué es filosofía, el acto de filosofar ofrece siempre una multiplicidad de perspectivas que dependen de la singularidad de sus artífices. Ahora, si estamos intentando sostener que el cine puede filosofar, hemos de preguntarnos si tras las imágenes hay un rostro.

Para dar respuesta a ambos interrogantes hemos optado, primero, por asumir una visión concreta del filosofar y, segundo, por reconocer la existencia de oficiantes tras las imágenes en movimiento. Deleuze nos ha servido de base para pensar la filosofía como un acto de tipo cartográfico. Su idea de que el filósofo crea conceptos sobre un plano de inmanencia está a la base de nuestro trabajo y nos interesa destacar el tono de cartografía porque, dicho con simpleza, el concepto oficia como trazo que da forma a un territorio. Y el territorio, que equivale al plano de inmanencia en su filosofía, condiciona y es, simultáneamente, producto del trazo. Bien, Deleuze nos señala que el arte 
(y pensamos el cine bajo esta égida) funciona por la creación de afectos. En este territorio la dimensión sensible del material de trabajo pareciera no ser, en principio, apta para los conceptos. Nos asegura que la filosofía se caracteriza por la creación de conceptos, el arte por la creación de afectos. ¿Es posible que el cine (entendido como arte) pueda crear conceptos para operar en una clave filosófica?

Hemos querido que esta pregunta persista a lo largo de nuestro trabajo antes de resolverla afirmativamente. Para intentar responder vale la pena auscultar si el cine, al igual que la filosofía, tiene la capacidad de pensar y de hacerlo respecto al afuera ${ }^{6}$.

¿Es el cine capaz de aportarnos una nueva manera de pensar? ¿Está en condiciones, en tanto cine, de presentarnos el pensamiento de una nueva manera y, al mismo tiempo, de hacernos pensar de un nuevo modo? ¿Hay una relación específica de la imagen-cine con el pensamiento? (DELEUZE, 2009, p. 550).

Debemos decir que si asumimos el pensamiento como una lucha con lo que nos rodea (y de diferentes modos ofrece resistencia) ciertos cines piensan y dan qué pensar. El cine en su relación con lo que se le opone debe pensar, por sus propios medios, cómo hacer una cartografía; dicho de otra forma, dar cuerpo a un territorio que a su vez condiciona el dispositivo que lo traza. En esa medida, nos preocupa el reconocer la capacidad de la imagen-movimiento como forma de pensamiento. Y para eso es necesario abandonar la idea de que las imágenes son un duplicado de una realidad de base. Comprendemos el trabajo del cine como una forma de inscripción, tal como lo sugiere Rancière (2010, p. 104): "Lo que llamamos imagen es un elemento dentro de un dispositivo que crea cierto sentido de realidad."

Comprender la imagen fuera del trabajo de duplicación de un mundo aparentemente natural nos permite dotarla con cierta dignidad ontológica. Podríamos decir, siguiendo a Deleuze, que la imagen-movimiento opera al

${ }_{6}$ Para Foucault, el pensamiento de la afuera ha supuesto una suerte de alegoría topográfica. En una clave que desafía a la epistemología conjetura que el adentro es un lugar para cartografiar, objeto de un mapa, delineable racionalmente. En contrapartida, el afuera supone un límite que franquea cualquier mapeo, que no puede ser objeto de conocimiento, que desafía la razón. De alguna manera es lo que se resiste a la conquista racional y desaparece cuando se considera conquistado. Deja de ser afuera para devenir adentro. Por ello Foucault opta por la literatura (creemos que el cine también lo hace) como herramienta que permite pensar el afuera. Lo hace al no domesticar, al abrir a cierto flujo que bien puede ser pre-lógico o a-lógico. El afuera, en suma, permite reflexionar de otro modo, permite expandir el adentro. Su fuerza es la de resistir y desaparecer. Resiste en tanto no es fácil de domesticar. Desaparece cuando creemos que logramos conquistarlo. 
igual que el concepto en tanto es un trazo sobre un nuevo tipo de territorio que, para nuestros efectos, no se agota en la pantalla. Sin embargo, no queremos sostener una postura que suponga que la imagen (para el caso del cine) o los conceptos (para la filosofía) determinan a voluntad el plano en que operan. Ello equivaldría a un radical idealismo nominalista; es decir, a sostener que lo que nombramos realidad es el resultado del trabajo de creación propio de los conceptos o las imágenes. Nuestra postura (parafraseando a Deleuze) supone el choque y la negociación. Un concepto da forma a un plano, pero el plano resiste al concepto. De igual modo, el cine nos entrega imágenes que dan forma al mundo que habitamos pero como resultado de una negociación con el afuera. Las imágenes encuentran resistencia en la dimensión material que, pese a toda fuerza gramatical, siempre aparece, a final de cuentas, indómita.

Badiou amplifica esta postura recordándonos que tanto filosofía como cine son trabajos de tipo creativo. Si la filosofía crea conceptos (a través del lenguaje verbal), el cine es capaz de dar cuerpo a ideas (a través de imágenes en movimiento). Su idea del séptimo arte como un medio artístico compuesto por bloques de movimiento-duración no solo sirve para caracterizar estructuralmente al cine, sino para revelar el lugar en que opera el cineasta. $\mathrm{Y}$ aquí queremos pensar nuestro segundo interrogante. Si asumimos que es posible concebir un cine capaz de dar cuerpo al filosofar es únicamente porque hay un cineasta capaz de configurar los bloques de movimiento-duración para dar qué pensar. En ello es imperioso reconocer al cineasta como homólogo del filósofo. Ahora, no necesariamente todos los directores de cine han de devenir filósofos. Creemos que los cineastas que logran materializar una poética singular, dar cuerpo a una obra que desafía los cánones institucionales del cine mismo, tiene mayor chance de hacer un cine con potencias filosóficas.

De esta forma es significativo el reconocimiento del cine de autor. Bajo esta etiqueta se aúna un esfuerzo por reconocer que el cine es un medio capaz de materializar la visión singular de un creador. Por eso creemos que la obra de los directores que pueden ser cobijados por esta categoría es un lugar propicio para pensar un nuevo escenario para la filosofía. Estudiar la poética de un director es una de las posibles rutas para reconocer la capacidad del cine de pensar el afuera y para dar qué pensar. Los bloques de movimiento-duración singularizados pueden hacer emerger situaciones filosóficas con cuantiosa riqueza. Dicho de otro modo, la poética se convierte, en términos metódicos, en táctica para la lectura de un cine filosófico. No se trata, por otra parte, de desahuciar a la palabra, o cuestionar la lengua como sistema propicio para la 
filosofía. La invitación es a pensar en cómo el cambio de sustancia expresiva (con su consecuente estudio) posee virtudes que, a fin de cuentas, engrosan el trabajo filosófico ${ }^{7}$.

\section{¿ES POSIBLE UN CINE POST-METAFÍSICO?}

Con el fin de explorar nuestra hipótesis de un cine capaz de dar cuerpo al ejercicio filosófico nos hemos situado en la modernidad del séptimo arte. Nos interesa este estrato de la historia del cine por dos razones puntuales. La primera porque en su seno ha tenido lugar la politica del cine de autor. En calidad de política, dicha postura es un intento por cuestionar el anonimato de los directores (convertidos en artesanos) concebidos en el cine clásico como simples piezas de un engranaje industrial. Se trata, en contraste, de reconocer que el cine tiene la dignidad de las bellas artes y que la autoría es posible a pesar del sistema colectivo de producción de un filme. La segunda razón tiene que ver con reconocer que la modernidad del cine supone un duro cuestionamiento al canon del cine clásico (en particular en términos expresivos). Dicho con simpleza, el modelo de representación institucional del cine clásico, como lo caracteriza Noël Burch (1995), oficia como una suerte de gramática que anquilosa la capacidad expresiva del medio. La potencia de los cineastas modernos tiene como sustento, en gran medida, un des-montaje del cine clásico, lo cual supone, como consecuencia, un esfuerzo poético notable.

Podríamos decir que tras el esfuerzo de los cineastas modernos, lo cual se constata en el trabajo poético singular, subyace una pregunta de naturaleza filosófica: ¿puede el cine hacer una crítica a la metafísica? La respuesta a esta pregunta está condicionada al tipo de concepción filosófica que hemos puesto en común con el séptimo arte. $\mathrm{Si}$, de la mano de Deleuze, hemos comprendido el trabajo filosófico como la creación de conceptos, de entrada se toma distancia del proceder metafísico. Para efectos de la discusión, se evade la tentación metafísica que sostiene que la filosofía es parasitaria de una

\footnotetext{
${ }_{7}$ El Grup Embolic, interesado en las potencias del cine para filosofar, insiste en que el séptimo arte opera de manera orgánica, no a partir de la fragmentación digital de la filosofía. "Mientras que la lectura (propia del trabajo filosófico) es una operación analítica y doblemente abstracta, que supone el análisis gramatical y lógico, el visionado de un filme solo puede llevarse a cabo sumergiéndose en él. Se trata de una operación sintética que se realiza principalmente de una manera global." (FERRER et al., 2006, p. 16). Dicho modelo sintético nos pone de cara a una dimensión expresiva con una estructura diferente. Por ello, se justifica que Debray afirme cómo el cine escapa al logos por ser un arte de síntesis. "El pensamiento por imagen (propio del cine) no es ilógico sino alógico. Tiene forma de mosaico, sin el relieve multiestratificado de una sintaxis." (DEBRAY, 1994, p. 273).
} 
realidad de base. Una filosofía de este tipo supondría una suerte de esfuerzo por encontrar una dimensión sustancial escondida. Ahora, si los conceptos dan forma a un plano, la realidad, por combate, no está dada sino que opera como acontecimiento.

Como sugeríamos, el cine clásico (propio de la imagen-movimiento), dado su afán por capturar la realidad de una manera fidedigna, puede ser caracterizado en términos metafísicos. Sus tres sistemas de configuración, como sugiere Bordwell (1997), tienen un marcado interés mimético-representativo. Causalidad, espacialidad y temporalidad rinden cuentas a la idea de duplicación de un supuesto mundo natural. Recordemos que este periodo de la historia del cine sistematiza diversos hallazgos que reclaman que las imágenes sean espejo y que la narración responda al principio de verosimilitud. No se trata de sugerir que el cine solamente ponga en pantalla historias basadas en hechos reales. En otro sentido, se sugiere que todo cine, independiente del origen de sus relatos, configura cada filme como si fuera una extensión del mundo natural. Eso supone que un filme fantástico puede sugerir un mundo completamente diferente al nuestro, incluso con reglas que rompan lo posible, pero que su modo de ser narrado respete las reglas del mundo que habitamos.

La modernidad, representada, en gran medida, por ciertos movimientos y vanguardias europeas, tiene un interés por des-montar el modelo de representación del cine clásico. En principio, si mantenemos la idea de una metafísica del cine la modernidad operaría, por lo menos, en calidad de crítica. En palabras de Badiou (2004, p. 40): "El cine es un arte de la época del fin de la metafísica”. Tras el trabajo de la modernidad se empiezan a cuestionar la capacidad del cine para ofrecer un doble de la realidad natural. Pero, más importante aún, se pone en duda que exista una realidad de base previamente configurada que pueda ser duplicada. Deleuze identifica este periodo de la historia del cine mediante la imagen-tiempo. Esta figura se caracteriza por debilitar el modelo de la acción causal para dar paso a situaciones de marcado acento visual-sonoro:

El cine moderno desarrolla nuevas relaciones con el pensamiento desde tres puntos de vista: el borramiento de un todo o de una totalización de las imágenes en provecho de un afuera que se inserte en ellas; el borramiento del monólogo interior en provecho de un discurso y de una visión indirecta libre; el borramiento de la unidad del hombre y el mundo en provecho de una ruptura que ya no nos deja más que una creencia en este mundo. (DELEUZE, 1986, p. 250). 
Rancière, por otra parte, señala que la modernidad supone cierto mutismo de la imagen que cuestiona la vocación narrativa del cine clásico. Así, este tipo de cine cuestiona una gramática aprendida de manera temprana hasta el punto que supone cierto ciframiento para los públicos. Pareciera que para poder violentar la metafísica del cine es necesario cuestionar su lenguaje, su afán de operar expresivamente como doble de una realidad de base. Emergen, en esta combinación, nuevas claves poéticas que, si bien pueden hermanarse, en su singularidad ofrecen mundos a partir de un trabajo de escritura.

Siguiendo a Deleuze, nos interesa resaltar esta idea porque supone una inscripción. En calidad de grabado en una superficie, toda inscripción hace surcos transformando lo que toca, pero, al mismo tiempo, puede horadar en la medida en que la superficie abre ciertas posibilidades de manipulación y otras no. De esta manera, el cine moderno no supone simplemente un acto de creación de mundos posibles como el sueño de un demiurgo. Es un ejercicio de dar forma al mundo por medio del trazo de la imagen cinematográfica. $Y$ esta imagen es, en el fondo, un modo de plegar el afuera, de hacer que la realidad (no tematizada) aparezca tras el trabajo poético de ciertos cines. Este tipo de cuestionamiento del trabajo metafísico hace que algunos cineastas del periodo moderno, más allá de la singularidad de sus poéticas, trabajen de modo coral. Su esfuerzo dignifica ontológicamente al cine en tanto lo considera un mecanismo capaz de dar forma a lo real.

Si bien la estructura del cine moderno, y en consecuencia el trabajo de los cineastas que se mueven a su interior, funciona como una suerte de des-montaje metafísico, esto no supone que los intereses poéticos de cada filmografía sean iguales. De tal forma, nos ha llamado la atención señalar que cada estrategia enunciativa es singular y por ello los intereses argumentales como los problemas filosóficos son variopintos. Los esfuerzos se encuentran al introducir modos de configuración alternativos que, de un modo u otro, cuestionan el lenguaje institucionalizado del séptimo arte. Podría pensarse, en consecuencia, que para desafiar la metafísica es necesario debilitar su lenguaje, hacer que opere de otro modo. Y esta es la gran cuota que aportan los cineastas de autor.

No obstante es posible reconocer, a modo de inventario, algunas estrategias del cine moderno para cuestionar la metafísica (estrategias que emergen como taxonomía cosecha de la presente investigación). Tal vez la primera de ellas sea el intento de materializar un cine de poesía. Dicho esfuerzo tiene como fin restituir a la imagen cierto misterio que le es vedado al 
ser subordinado al universo del relato. Liberar a la imagen de una dimensión funcional, que solo ilustra un proceso narrativo, rompe con la red de causalidad que la apresa hasta casi lexicalizarla. Convertida en trampa visual, en el cine moderno, la imagen hace imperativo un ejercicio exegético y se presta para inocular en su piel algún tipo de idea o situación filosófica. Una segunda estrategia, propia de la modernidad, tiene lugar en la figura de la ruina, la cual puede ser pensada como forma narrativa que sabotea el preciosismo formal del cine clásico o puede ser objeto de representación visual/narrativa que revela, en clave alegórica, la imposibilidad de un relato para ser copia (o extensión natural) de un mundo dado. Una tercera estrategia que puede reconocerse es la puesta en evidencia del artificio. En contravía del cine clásico, que busca esconder la factura de sus filmes, el cine moderno revela su artificiosidad. Como si se tratara de una poética defectuosa el canon clásico es saboteado. Lo interesante es que, en muchos casos, lo que debería romper el efecto de naturalidad lo reafirma. Una lección que pareciera enseñar que configurar un mundo es posible por una ruta no metafísica.

Creemos que al interior de cada filmografía de autor puede tener lugar una mirada sobre problemas de interés filosófico. Y que, gracias al trabajo poético de cada director, pueden dar qué pensar. Entre las tareas por venir, diríamos, tienen lugar dos rutas importantes. La primera tiene que ver con el acercamiento al cine de autor para dar lugar a una exégesis filosófica. En otras palabras, invitar a leer los bloques de movimiento-duración como territorios para situaciones filosóficas. Esto, sin duda, supone un cambio en la postura del espectador, un trabajo que varíe la clave interpretativa. ¿Qué podrá encontrarse? Un misterio, en el más literal de los sentidos. La segunda ruta nos regresa a nuestra pregunta sobre la filosofía como creación de conceptos. La respuesta es que el cine tiene la capacidad de dar paso a conceptos (a través de las imágenes en movimiento) si se piensa que su dimensión expresiva tiene la capacidad retórica de desplazar el trabajo abstracto o por lo menos evocarlo. En el fondo, las palabras funcionan del mismo modo. Tal vez solamente hemos naturalizado el lenguaje como territorio para el pensamiento conceptual, olvidando que su modo de operar (por convencional que sea) siempre supone un trabajo traslaticio. Reconocer todo el arsenal expresivo del séptimo arte es el primer paso, pero no es suficiente para creer que en medio de las imágenes en movimiento, las cuales dan qué pensar, también los conceptos aparezcan en calidad de incorporales. Esa tarea, por lo menos hasta que se ensanche el análisis, depende del trabajo poético de los directores como de los puentes con la filosofía misma. 
Badiou nos asegura que la existencia de conceptos en el cine tiene lugar gracias a que el séptimo arte establece intercambios con la filosofía al señalar: "Si somos capaces de hacer conceptos filosóficos a partir del cine es porque transformamos las síntesis filosóficas en el contacto con las nuevas síntesis cinematográficas." (BADIOU, 2004, p. 48). Así, bien podemos decir que el cine, en general, es capaz de ofrecernos, mediante imágenes-pensamiento, nuevos conceptos. Incluido, claro, el cine clásico aunque con el paso del tiempo su producción conceptual se petrifique. El cine moderno supone variaciones sobre conceptos previos (en tal medida, una re-figuración del cine clásico). Y ese proceso bien puede tender un puente con el esfuerzo filosófico de orbitar, una y otra vez, sobre lo pensado; un ejercicio de volver sobre los conceptos hasta agotarlos, paradójicamente, por exceso de pensamiento.

\section{Figuras FiLOSÓficas}

\section{LA POÉTICA DEL CINE ASIÁTICO}

Quisiéramos poner a prueba alguna de estas tentaciones con una obra de autor y, al mismo tiempo, intentar expandir la idea de un cine con inclinaciones filosóficas más allá de la modernidad cinematográfica (principalmente europea). Como hemos sugerido, los bloques de movimientoduración propios de la imagen-tiempo, en tanto señala Deleuze, han dado pie a un trabajo que desafía la visión metafísica del cine clásico. Todo ello, a grandes rasgos, ha tenido lugar en la segunda mitad del siglo pasado en la Europa continental. Bien podría pensarse en cineastas-autores como Godard, Herzog, Antonioni o Tarkovski en tanto artífices de poéticas capaces de dar qué pensar, hacer que las imágenes den paso a nuevas variaciones conceptuales. ¿Puede esta dinámica operar en otras geografías? Y la respuesta, en principio, es que sí en tanto el cine encuentre el modo de evadir una postura metafísica. Entendemos que un buen ejemplo es la filmografía del director hongkonés Wong Kar-Wai. Sin duda, uno de los exponentes del cine de autor contemporáneo (incluso nos atreveríamos a decir postmoderno) que, gracias a una re-descripción de las estrategias de resistencia de la imagen-tiempo, ha formulado sus propias figuras de pensamiento estrechando los vínculos entre la filosofía y el séptimo arte.

Ahora bien, como señalamos, nos adentramos al análisis de parte de la obra iniciática de Wong Kar-Wai rodada en la última década del siglo: Days of being wild (1990), Chungking express (1994), Fallen angels (1995), 
Happy together (1997) e In the mood for love (2000). Como sugiere Gordon (2013), la excusa narrativa de nuestro director es la nostalgia. Y diríamos, con mayor precisión, una reescritura de lo nostálgico cuyas estrategias bien pueden ser la reconstrucción de otra época y la constante amenaza de un tiempo imposible. En otras palabras, su filmografía, en conjunto, supone un interés por otro periodo (la década del sesenta es tal vez la clave) y, a la par, una ańoranza por un tiempo que no se realiza, lo cual sugiere un sabotaje del tiempo cronológico. En sus relatos los personajes no ańoran acontecimientos del pasado sino acontecimientos que no han tenido lugar (un extraño tiempo potencial aparentemente frustrado). La nostalgia como coartada da como resultado un trabajo sobre la temporalidad. Así, nuestro director nos ofrece una re-figuración del tiempo que evita el modelo cronológico y la intratemporalidad pura. La salida es una inscripción del tiempo (como pasado nostálgico, como futuro irrealizable) sobre unos cuerpos que se consumen en una cruda nostalgia.

Carlos F. Heredero (2002) sugiere que el tiempo en Wong Kar-Wai opera bajo la figura de la herida. A la par, Francisco José Gómez (2008) nos dice que el tiempo (indisociable del espacio) se materializa en la figura de la grieta. Ambos autores, sin lugar a dudas, revelan cómo la poética de nuestro director ofrece otro modo de pensar el tiempo mediante diversas figuras de pensamiento. Heredero nos sugiere que el tiempo deviene poesía hasta el punto de operar como una variable mental al señalar que:

El tiempo no es para ellos (los personajes) un concepto vacío (simple oficio de los relojes que los asedian por doquier, o algo que simplemente transcurre) sino una dimensión vibrante, dotada de espesor y de vida propia, íntimamente vinculada con su vida emocional y con su propia dinámica interior. (HEREDERO, 2002, p. 18).

Desde su perspectiva, Wong Kar-Wai es un cronista del presente capaz de materializar, bajo su lente, ciertas formas incorporales o, por lo menos, de preocuparse por visibilizarlas (diríamos, los objetos son extensiones sensibles de los seres humanos). Pero lo central es que tales situaciones solamente tienen interés si pueden perdurar, si puede hacer una inscripción temporal (posiblemente herir al tiempo mismo para que dirijamos nuestra mirada sobre él): "Empeńado en capturar las huellas del presente que se hace pretérito en el mismo momento que lo filma con la cámara." (HEREDERO, 2002, p. 
19). Posiblemente esto justifique la figura de la herida como perforación. Herir supone que una superficie sea agujereada, pierda su propia elongación perfecta. Y el tiempo medido ha sido siempre una línea recta. Wong Kar-Wai decide perforar a Cronos hasta hacerlo sangrar.

Gómez, por otra parte, nos sugiere la figura de la grieta para pensar el espacio-tiempo de nuestro director. $\mathrm{Y}$ esta figura bien puede entenderse, como él mismo lo reconoce, como un correlato de la herida al afirmar que:

El término félure indica, además de una herida, la fisicidad de ésta, la existencia de un principio y un final para ella, pero también el recubrimiento de un vacío, y ese vacío se constituye en una grieta que podemos aplicar a la polivalente relación entre el espacio y el tiempo en los filmes de Wong Kar-Wai. (GÓMEZ 2008, p. 7).

Tras perforar el cuerpo de Cronos no podemos evitar la pulsión voyerista de mirar, a través de la rasgadura, como si fuera una abertura espaciotemporal. La grieta es, sin dudas, una mirilla, en este caso cinemática que, como bien indica el autor, invita al espectador a dar sentido (con imágenes en movimiento) a la puesta en evidencia (la visibilización en primer término) de la espacio-temporalidad. Puede reconocerse en este interés de privilegiar la escritura del espacio y del tiempo un rasgo de la modernidad cinematográfica. Como respuesta al privilegio de la causalidad dramática del cine clásico, los cineastas modernos des-ligan el espacio-tiempo de las acciones narrativas. "Wong Kar Wai presenta una complejización visual del espacio y de la visualidad misma que hacen referencia a los mismos problemas abordados por los modernos." (GORDON, 2013, p. 19).

Tras la estela de estas figuras que dan qué pensar (nostalgia, herida, grieta) nosotros ambicionamos sugerir que Wong Kar-Wai nos ofrece un desmontaje metafísico del espacio-tiempo en una clave lírica. Es decir, su cine nos ofrece imágenes-pensamiento sobre el modo en que el espacio-tiempo es objeto de una escritura que exalta una dimensión emotiva. Lo importante en este caso es que dicha escritura es posible sobre una singular noción de las materialidades cinemáticas. Podemos reconocer otro modo de pensar el espaciotiempo por su capacidad de tatuarse en diferentes soportes materiales (cuerpos, viejos objetos, arquitecturas derruidas). La excusa del amor, metamorfoseado en diversos ropajes, adquiere un matiz singular porque es dibujado por un espacio-tiempo lírico actualizado en un conjunto de imágenes que desafían cualquier forma de duplicación de un referente natural. "Es como si Wong 
Kar-Wai nos quisiese decir que del amor y del sufrimiento no es posible dar cuenta a través de palabras, y es tan sólo a través de imágenes cifradas como podemos registrar su presencia incomprensible." (SALAZAR, 2010, p. 92).

Sin duda, esto es posible porque nuestro director se vale de diversas potencias técnicas del séptimo arte. En el registro espacial encontramos, como tendencia, una composición barroca de la imagen, una puesta del cuerpo humano en segundo término que privilegia (hasta magnificar) objetos cotidianos, una cámara ligera, casi frenética ${ }^{8}$, que sugiere puntos de vista aberrantes, el uso de lentes que deforman lo que tocan. En el registro temporal, una alteración radical de la duración de los acontecimientos en clave lírica (ralentizados extremos), contraste de movimientos que superponen tiempos (cuerpos estáticos y objetos a alta velocidad en un mismo plano), extensos planos que consumen, temporalmente, todo lo que tocan.

En términos argumentales, nuestro director se ha interesado por realizar un retrato de las complejas relaciones afectivas en las grandes y laberínticas megalópolis contemporáneas (principalmente Hong-Kong). Los espacios urbanos contemporáneos ofician en calidad de cuerpos que afectan a los protagonistas de sus historias condicionando sus difíciles interacciones interpersonales. En su periodo iniciático bien podemos encontrar, como constante, una fractura en la relación afectiva que desemboca en la nostalgia. A diferencia del cine clásico, que recompensa con el final feliz en el cual las parejas alcanzan un amor idílico, en el cine de nuestro director el vínculo es suspendido (siempre arruinado por un tiempo potencial). Amor no correspondido (Days of being wild), amor fracturado (Fallen angels), amor imposible (In the mood for love), amor invisible (Chunking express) bien podrían ser los trazos que, en términos argumentales, motivan sus historias. De allí que el amor siempre opere en clave nostálgica, literalmente como una herida asociada a un tiempo imposible, que frustra la actualización del deseo. En el caso de Days of being wild, nuestro protagonista evade los vínculos afectivos. Dos mujeres se enamoran de él, pero más allá de los encuentros sexuales son anuladas. Él, a su vez, es objeto de la anulación de su madre sustituta que desea abandonar el país y de su madre biológica que no quiere verlo. En Chunking express nuestro protagonista sufre los estragos de una ruptura amorosa. Continúa su vida añorando su vieja relación, viviendo al filo de un quizás. Y sin saberlo, una

\footnotetext{
8 Podemos, no obstante, resaltar que esta realización no es generalizable a todas las películas del director, como es el caso del filme In the mood for love, en el cual observamos, como excepción, una marcada cámara lenta.
} 
singular joven que trabaja en una pequeña cafetería que frecuenta se enamora de él. Ella teje una relación con él que no existe. Visita el apartamento de nuestro protagonista cuando él no está y hace los quehaceres hogareños como una novia cuida los espacios de su amado.

En el film Happy together encontramos una situación que suma al des-encuentro amoroso, la nostalgia espacial (por lo menos en una clave genealógica). Esta historia nos narra el periplo de una pareja homosexual que está radicada en Buenos Aires, Argentina. Sin mayor motivo que el viaje de evasión, sueñan con visitar las caratas de Iguazú (lo cual nunca ocurre, como si el espacio imposible fuera un presagio de un futuro imposible). La nostalgia supone tanto un espacio mítico, como un espacio de origen. Las cataratas, con toda su simbólica hidráulica, suponen la fuerza de un espacio prometido (pero irrealizable), extrańa actualización del mito que poetiza un espacio inevitable. Como contra punto, Hong Kong, lugar de origen de nuestros protagonistas, es un espacio nostálgico que siempre reclama el retorno. Si bien el regreso tiene lugar para uno de nuestros protagonistas, esto no supone un tipo de satisfacción sino el reconocimiento de que la nostalgia se desplaza a otros espacios. Como si siempre toda espacialidad supusiera, en términos de actualización, un des-encuentro, un por-venir potencial. Y es que dicho personaje teje amistad con otro migrante luego de terminar con su compañero sentimental en suelo argentino y, ahora de nuevo en Hong Kong, lo embarga la nostalgia del otro viajero. Dicho personaje viaja hasta un faro en la Patagonia, lugar que es considerado el fin del mundo. Espacio poético que en su literalidad geo-gráfica solo supone la búsqueda de nuevos espacios para la supervivencia afectiva.

La figura del des-encuentro, que supone un modo de reconocer el espacio como obstáculo, tiene un interesante tratamiento en In the mood for love. En este filme se nos narra la historia de dos personajes cuyas respectivos cónyuges los engañan entre sí. Estamos de cara a una singular unión fruto de una extrańa infidelidad, pues encuentran consuelo mutuo tras el engaño. Y, si bien se enamoran, su amor solo es una potencialidad frustrada. En este caso la ciudad es el territorio de des-encuentro, pero no como un simple escenario sino como un cuerpo nostálgico que les miente sugiriéndoles que la cercanía física es posible para luego separarlos a pesar de la corta distancia que media entre ellos. En medio de unas calles sinuosas, de pequeños callejones, de extrańos obstáculos materiales, el encuentro se hace imposible. Presenciamos el peso arquitectónico del espacio que revela la parálisis del cuerpo. Ya no 
estamos en el cine clásico en el que el héroe, dueño de la acción, domestica la espacialidad. En este caso, es el espacio el que cartografía los cuerpos hasta hacer de ellos unos singulares apéndices.

Fallen angels es otro interesante caso del peso de la ciudad sobre los cuerpos de los personajes. En este film tenemos dos protagonistas masculinos. El primero de ellos, un asesino a sueldo, debe vivir desplazándose constantemente, irónicamente, atrapado en la movilidad. Los espacios son amenaza fortuita, imposibilidad para amar, lo cual, en este caso, supone una morada. El segundo de ellos, que sufre un extrańo mutismo (aunque escuchamos en off su voz interna) entra a hurtadillas en la noche a diferentes negocios y finge ser el dueño de ellos. Estos lugares ajenos le permiten gozar de familiaridad en la medida en que puede devenir otro. Las memorables escenas de la placidez en medio de un espacio cotidiano amplifican la búsqueda de afectividad en medio de la materialidad urbana.

Como bien sugieren tanto Heredero como Gómez, en el cine de nuestro director los objetos (que son siempre formas espaciales) tienen la capacidad de operar en clave afectiva. No es gratuito encontrar a nuestro personaje hablando a ciertos objetos, interrogándolos como portadores de sentido. Gómez destaca las lágrimas (objetos somáticos) que bien sabemos se asocian a un estado anímico. Y estas se metamorfosean en la filmografía de nuestro director en múltiples direcciones. Desde caer lentamente por el rostro de alguno de nuestros personajes, pasando por las cruentas lluvias urbanas, hasta la fuerza demoledora de las cataratas. Esta metamorfosis no es gratuita ni simplemente figurada. Es un acto de reconocer cómo la espacialidad afecta y es afectada por los cuerpos. En una escena de Chungking express, luego de que el pequeño apartamento del protagonista se inunda, lo escuchamos preguntarse por la manera en que una casa puede llorar. $Y$ en ese gesto de desplazamiento se dona al espacio de la afectividad humana, como las lluvias que bien describen la nostalgia de ciertos cuerpos.

Queremos creer que en la escritura del tiempo a nuestro director poco le atrae la cronología. A su cine no le interesa una mimesis del tiempo del reloj. Sin embargo, funciona en una redescripción del tiempo, siempre consciente de que éste es figurado por la misma capacidad del dispositivo de inscripción (en este caso el cine). Sus imágenes-tiempo (op-signo y son-signos puros) presentifican que el tiempo únicamente es posible como marca sobre una materialidad. Y quizás su presencia sea más fuerte cuando lo que toca, de un modo u otro, se arruina. No se trata de un tiempo psicológico, ni de una pura 
intratemporalidad; aquí la cámara, como ciertas formas de escritura propias del montaje, hace evidente la técnica que hace al tiempo. Son recurrentes las cadencias de la estilográfica visual para desafiar el movimiento de los cuerpos como si intentaran violentar su propio movimiento. Y dicha violencia se hiperboliza en las imágenes ralentizadas sobre ciertos objetos. Se repite un singular juego de stop-motion que elimina fragmentos visuales para mostrar la velocidad del movimiento y, simultáneamente, la lentitud del cuerpo. De allí que bien podamos saber que los personajes casi siempre estén a la espera y, a fin de cuentas, la espera no se realice, el tiempo no se agote. Mejor, podríamos decir, consuma a los cuerpos. En Chungking express presenciamos (en varias escenas) cómo los protagonistas, frustrados afectivamente, y en un singular gesto nostálgico, son encuadrados por la cámara en primer tiempo con una mirada sin objeto. Están suspendidos en el tiempo. Lo principal es que presenciamos, en segundo término, querellas a alta velocidad entre otros personajes. El tiempo consume al cuerpo hasta suspenderlo, hacerlo devenir in-corporal en medio de la monstruosidad urbana. En In the mood for love los amantes imposibles se encuentran en medio de una ciudad de callejón. Nuestro director ralentiza la imagen para hiperbolizar el des-encuentro entre los cuerpos. La capacidad lírica de la lentitud, acompasada por una poderosa música, arruina la relación intersubjetiva, destruye el cuerpo en su movimiento falsamente natural. Se hace una escritura del cuerpo como superficie de un tiempo poético.

\section{A manera de Colofón}

Para terminar quisiéramos señalar que Wong Kar-Wai nos regala una redescripción del espacio-tiempo en con-tacto con la materialidad que no solo muestra las afectaciones mutuas sino su posible escritura poética. Si bien este es el trabajo propio de muchas artes, en el caso del cine de nuestro director se amplifica porque su escritura revela dichas relaciones en una clave cifrada. Como bien sugiere Salazar (2010) lo interesante es que sabemos cómo el espacio-tiempo es condición de nuestra existencia, en este caso, el misterio no se resuelve. Más que un relato sobre la fuerza espacio-temporal, asistimos al devenir sensible del espacio-tiempo capaz de tatuar cualquier clase de superficie. Dicha explicación, a su vez, no agota la potencia de dicha inscripción. Se demuele la metafísica del espacio-tiempo como condición natural, se evita la visión espacio-temporal como una marca psicológica. 
No queda más que el trabajo de creación a través de imágenespensamiento lo suficientemente discretas (incluso propias del mutismo que interesa a Rancière) que nos invitan a pensar. Creemos que con las figuras de pensamiento, los conceptos son una deriva cercana. La poética de nuestro director (que si bien tiene origen en la modernidad cinematográfica la sobrepasa) lo convierte en un filósofo interesado en la afectividad (en el más profundo sentido del con-tacto), interesado en unos cuerpos que pueden mucho más de lo que creemos, en especial porque son retratados mediante un espacio-tiempo que violenta el lenguaje gramaticalizado (léase cine clásico). Sin pretender abarcar todos los matices filosóficos de la obra de Wong KarWai, podemos concluir que su capacidad de filosofar en el cine radica en poner en escena una filmografía del des-encuentro. Con ello, creemos, se revela la manera en que una poética de autor puede dar paso a imágenes-conceptos. Expansión de la filosofía en que, como colofón, hemos de decir que la voz del filósofo deviene narrativa-visual. Y saber leerla se convierte en la tarea de una filosofía que crea conceptos en un nuevo territorio.

ALVARADO DUQUE, C. F. Can the cinema give us ideas? Wong Kar-Wai and the poetics of dis-encounter. Trans/form/ação, Marília, v. 42, n. 3, p. 171-190, Jul./Set., 2019.

\begin{abstract}
Aвstract: Is it possible for the cinema to philosophize? Can the moving image work as a means for philosophy to operate under a different expressive language? This article discusses the ability of certain cinemas (especially modern cinema) to do philosophy on the big screen. It describes the theoretical approaches that argue for a philosophical cinema capable of offering concepts through the expressive dimension of moving images. This process takes place within the poetic work that an auteur's cinema offers which, because of its distance from the general tone of classical cinema, implies a critique of metaphysics from within the territory of the seventh art. The article analyzes part of the early work of the director Wong Kar-Wai's and his unique poetics of dis-encounter (an expression we have coined to characterize the work of the Hong Kong filmmaker). Through his work on the margins of modern cinema, it is possible to show how the seventh art can offer us something to think about.
\end{abstract}

KeYwords: Cinema. Philosophy. Poetry. Metaphysics. Wong Kar-Wai.

\title{
REFERENCIAS
}

BADIOU, A. Acerca de "Qué es tener una idea en cine" de G. Deleuze. In: BADIOU, A. (ed.). Pensar el cine 1: imagen, ética y filosofía. Buenos Aires: Manantial, 2004. p. 23-81. 
BORDWELL, D. El cine clásico de Hollywood: estilo cinematográfico y modo de producción hasta 1960. Barcelona: Paidós, 1997.

BURCH, N. ¿Un modo de representación primitiva? In: BURCH, N. El tragaluz del infinito. Madrid: Cátedra, 1995. p. 193-2014.

CARROLL, N.; CHOI, J. Philosophy of film and motion pictures. Malden: Blackwell, 2006.

CAVELL, S. La busqueda de la felicidad: la comedia de enredo matrimonial en Hollywood. Barcelona: Paidós, 1999.

DEBRAY, R. Vida y muerte de la imagen: historia de la mirada en Occidente. Barcelona: Paidós, 1994.

DELEUZE, G. La imagen-tiempo: estudios sobre cine 2. Barcelona: Paidós, 1986.

. Cine I: Bergson y las imágenes. Buenos Aires: Cactus, 2009.

FERRER, A. et al. Primum videre, deinde philosophari: una historia de la filosofía a través del cine. Valencia: Institució Alfons El Magnànim, 2006.

FRAMPTON, D. Filmosophy. London: Wallflower, 2006.

GÓMEZ, F. J. Wong Kar-Wai: grietas en el espacio-tiempo. Madrid: Akal, 2008.

GORDON, J. B. Modernismo y cine después de la postmodernidad: el caso de Wong Kar-Wai. Razón y Palabra. Revista Electrónica en Iberoamérica Especializada en Comunicación, n. 84, p. 513-533, 2013.

HEREDERO, C. La herida del tiempo: el cine de Wong Kar-Wai. Valladolid: 47. Semana Internacional del Cine, 2002.

RANCIÈRE, J. El espectador emancipado. Pontevedra: Ellago, 2010.

SALAZAR, J. Wong Kar-Wai y la poética del secreto. Revista Metapolitica, v. 68, p. 88-92, enero-marzo 2010.

WARTENBERG, T. Thinking on screen: film as philosophy. New York: Routledge, 2007.

Recebido: 28/11/2016

Aceito: 18/07/2018 
ALVARADO DUQUE, C .F. 